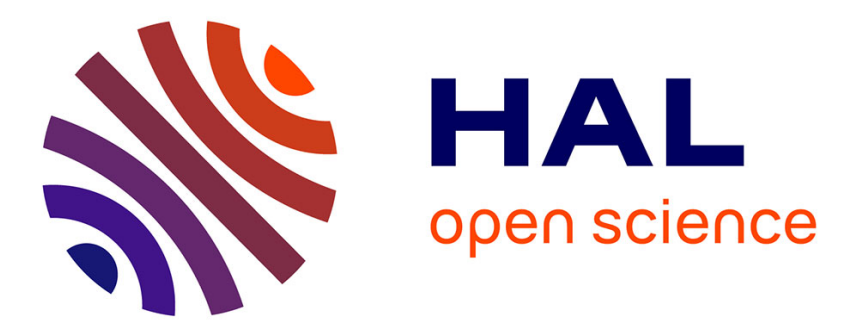

\title{
A role of frk in regulation of embryonal pancreatic beta cell formation
}

Björn Åkerblom, Cecilia Annerén, Michael Welsh

\section{To cite this version:}

Björn Åkerblom, Cecilia Annerén, Michael Welsh. A role of frk in regulation of embryonal pancreatic beta cell formation. Molecular and Cellular Endocrinology, 2007, 270 (1-2), pp.73. 10.1016/j.mce.2007.02.009 . hal-00531918

\section{HAL Id: hal-00531918 https://hal.science/hal-00531918}

Submitted on 4 Nov 2010

HAL is a multi-disciplinary open access archive for the deposit and dissemination of scientific research documents, whether they are published or not. The documents may come from teaching and research institutions in France or abroad, or from public or private research centers.
L'archive ouverte pluridisciplinaire $\mathbf{H A L}$, est destinée au dépôt et à la diffusion de documents scientifiques de niveau recherche, publiés ou non, émanant des établissements d'enseignement et de recherche français ou étrangers, des laboratoires publics ou privés. 


\section{Accepted Manuscript}

Title: A role of frk in regulation of embryonal pancreatic beta cell formation

Authors: Björn Åkerblom, Cecilia Annerén, Michael Welsh

PII: $\quad$ S0303-7207(07)00098-6

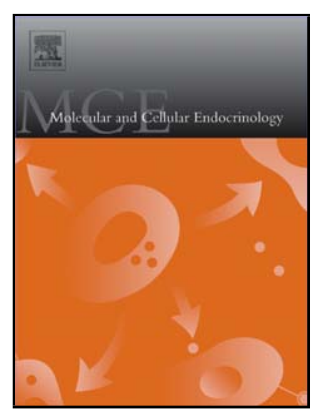

DOI: doi:10.1016/j.mce.2007.02.009

Reference: MCE 6627

To appear in: Molecular and Cellular Endocrinology

Received date: 27-10-2006

Revised date: 8-2-2007

Accepted date: 22-2-2007

Please cite this article as: Åkerblom, B., Annerén, C., Welsh, M., A role of frk in regulation of embryonal pancreatic beta cell formation, Molecular and Cellular Endocrinology (2007), doi:10.1016/j.mce.2007.02.007

This is a PDF file of an unedited manuscript that has been accepted for publication. As a service to our customers we are providing this early version of the manuscript. The manuscript will undergo copyediting, typesetting, and review of the resulting proof before it is published in its final form. Please note that during the production process errors may be discovered which could affect the content, and all legal disclaimers that apply to the journal pertain. 


\title{
A ROLE OF FRK IN REGULATION OF EMBRYONAL PANCREATIC BETA CELL FORMATION
}

\section{Björn Åkerblom*, Cecilia Annerén\# and Michael Welsh*}

\author{
*Department of Medical Cell Biology, Uppsala University, Uppsala, Sweden \\ \# Department of Cell and Molecular Biology, Karolinska Institute, Sweden
}

Address for correspondence:

Michael Welsh

Dept of Medical Cell Biology, Uppsala University

Husargatan 3, Box 571, 75123

Uppsala, Sweden

Phone: 46-18-4714447

Fax: 46-18-4714059

E-mail: Michael.Welsh@mcb.uu.se

Running title: FRK affects embryonal beta cell number 


\section{Summary}

The Fyn-Related-Kinase is a non-receptor tyrosine kinase expressed in various tissues, among them, the is lets of Langerhans. The role of FRK in pancreatic beta cells has been addressed by studies of knockout or FRK-trans genic mice. These experiments have shown that FRK overexpression in beta cells leads to an increased susceptibility to the beta cell toxin strepto zotocin and to cytotoxic cytokines, suggesting that FRK may participate in events leading to beta cell destruction. However, these mice also exhibit an increased relative beta cell volume and increased beta cell replication following partial pancreatectomy, suggesting a positive role for FRK in the regulation of beta cell number as well.

To further assess the significance of FRK for beta cell replication, we studied the beta cell area and is let cell replication in FRK null mice. We currently observe that the FRK-knockout mouse showed no difference in the insulin positive cell area or in the percentage of Ki67-stained proliferating islet cells at adulthood, when compared to wild-type control. In addition, adult FRK-/- mice performed normally when subjected to an intravenous glucose tolerance test.

To elucidate whether FRK affects pancreatic beta cell number during embryogenesis and shortly after birth, pancreata were collected from FRK-/- mice at these stages. Histological analysis of insulin stained pancreatic sections showed that the insulin positive cell area in FRK-/- mice was reduced at embryonal day 15 and at birth to $31 \%$ and $70 \%$ of that of wild-type mice, respectively. FRK -/- pancreas weight on day 1 neonatally was similar to that of the control, indicating that the obtained results were not due to altered pancreatic growth.

Taken together these results show that FRK affects beta cell number during embryogenesis and early in life, but is probably redund ant for beta cell number and function in adult animals under normal conditions. 


\section{Introduction}

FRK is a Src-like non-receptor intracellular tyrosine kinase. Mouse FRK was originally cloned from the mouse insulin-producing cell line betaTC-1 (Oberg-Welsh and Welsh 1995). Screening has revealed expression of FRK in a numerous tissues, most pronounced in intestine, pancreas and kidney. Islets from Rat Insulin PromoterFRK transgenic mice display increased sensitivity to cytokines and to the beta cell toxin streptozotocin. FRK has thus been proposed to be involved in mediating events leading to type- 1 diabetes. However, adult RIP-FRK transgenic mice have a slightly enlarged pancreas, nearly doubled beta cell area relative to total pancreas, and display increased beta cell replication after $60 \%$ pancreatectomy, suggesting a positive role of FRK-overexpression in regulating the beta cell mass (Anneren 2002; Anneren and Welsh 2001). A FRK null mouse, generated by Chandrasekharan et al (Chandrasekharan, et al. 2002), is essentially normal with the exception that it displays reduced levels of circulating T3 hormone and a moderate up regulation of Src in the intestine. Interestingly, islets of Langerhans from FRK -/- mice exhibit a reduced sensitivity to cytotoxic cytokines in vitro (Welsh, et al. 2004) pointing to a non-redundant function of FRK.

The fact that RIP-FRK transgenic mice exhibit an increased beta cell area raises the possibility that FRK plays a role in regulating beta cell replication/formation. To address this further, we investigated the percentage area of beta cells in embryonic and adult FRK knockout mice.

\section{Materials and Methods}

\section{Animals}

FRK-/- mice (Chandrasekharan et al. 2002) was originally of C57BL/6J/129Sv/Ev mix, for this work mated 4 to 10 generations with C57BL/Ks mice. For all experiments, wild type littermates were used as controls, except when otherwise stated. All animal experimentation was approved by the local animal ethics committee at Uppsala University.

\section{Histological procedures}

Pancreata from day 1 neonatally and from 2,5 month old FRK-/- or wild type mice were fixed in $4 \%$ paraformaldehyde or $10 \%$ formalin respectively, and embedded in 
paraffin. Sections, $5 \mu \mathrm{m}$ thick, were cut and mounted on glass slides. The glass slides were stain ed with anti-insulin or anti-glucagon antibody. Reagents \& dilutions: swine serum (Vector Laboratories Inc, Burlingame, CA, USA) 1:50, primary antibodies: guinea pig antihuman insulin serum (Chemicon International Inc, Temecula, CA, USA) 1:640 and anti-glucagon (Novo Nordisk A/S, Bagsværd, Denmark) 1:2000, secondary antibody: polyclonal swine anti-rabbit IGs (DakoCytomation Denmark A/S, Glostrup Denmark) 1:20, PAP rabbit polyclonal (DakoCytomation Denmark A/S, Glostrup Denmark) 1:100. Staining was performed as follows: sections were blocked for $10 \mathrm{~min}$ with $6 \%$ hydrogen peroxidase in PBS, then washed and blocked 30 min with serum. They were incubated 2 hours with primary antibody, washed, covered with secondary antibody for $30 \mathrm{~min}$, washed and incubated $30 \mathrm{~min}$ with PAP. After that the sections were washed, followed by $10 \mathrm{~min}$ in diaminobenzidine tetrahydrochloride 1:50 to develop staining. The staining reaction ended by incubation in tap water for $10 \mathrm{~min}$. PBS was used for all washing steps. The glass slides were then rinsed with distilled water, stained with hematoxylin solution, dehydrated and mounted with coverslips. Sections from 2.5 month-old mice were not counterstained with hematoxylin in order to enable computer-based identification of stained versus unstained area, when assessing insulin positive area relative to total section area. Pancreata from E15.5 FRK -/- or wild type mice were fixed in 4\% paraformaldehyde and embedded in paraffin. Sections, $10 \mu \mathrm{m}$ thick, were cut and mounted on glass slides. The glass slides were stained with primary antibodies as above and with secondary antibody: donkey anti-guinea pig rhodamin (Jackson ImmunoResearch Laboratories Inc, West Grove, PA, USA).

Pancreata from 3-5 month old FRK-/- and wild-type mice were fixed in 10\% formalin and embedded in paraffin. Five $\mu \mathrm{m}$ sections were stained with Ki67 antibody. Reagents \& dilutions: Target Retrieval Solution (DakoCytomation Denmark A/S, Glostrup Denmark), Protein Block (DakoCytomation Denmark A/S, Glostrup Denmark), Monoclonal rat anti-mouse Ki67 clone TEC-3 1:600 (DakoCytomation Denmark A/S, Glostrup Denmark), secondary antibody: Polyclonal rabbit-anti rat biotinylated immunoglobins 1:200 (DakoCytomation Denmark A/S, Glostrup Denmark), ELITE PK-6100 (Vector Laboratories, Inc, Burlingame, CA, USA). Stain ing was performed as follow: Sections were blocked for 10 min with $6 \%$ hydrogen peroxidase in TBS, then washed and put in preheated Target Retrieval Solution and steamed for $20 \mathrm{~min}$ in a Braun food steamer. Sections were allowed to 
cool for $45 \mathrm{~min}$, and after that washed with TBS three times, then blocked $30 \mathrm{~min}$ with Protein Block. After blocking, the section s were incubated over night with Ki67 antibody, washed, covered with secondary antibody for $30 \mathrm{~min}$, washed and incubated 30 min with Elite PK-6100. After that the sections were washed, followed by $10 \mathrm{~min}$ in diaminobenzidine tetrahydrochloride $1: 50$, hydrogenperoxide $0.006 \%$, to develop staining. The staining reaction ended by incubation in tap water for $10 \mathrm{~min}$. TBS was used for all washing steps. The glass slides were then rinsed with distilled water, stained with hematoxylin solution, dehydrated and mounted with coverslips.

For double staining of pancreas with Insulin and Ki67, sections were blocked with Goat serum (Vector Laboratories Inc, Burlingame, CA, USA), incubated with primary antibody: guinea pig antihuman insulin serum (Chemicon International Inc, Temecula, CA, USA) 1:200. Then washed with TBS and incubated with secondary antibody: biotinylated goat anti rabbit 1:400 (Southern Biotech, www.southernbiotech.com). Thereafter sections were treated with Alkaline phosphatase standard kit AK 5000 (Vector Laboratories Inc, Burlingame, CA, USA), washed with TBS and subsequently developed with Vector red substrate kit 1 AK 5100 (Vector Laboratories Inc, Burlingame, CA, USA). After insulin staining, sections were stained with Ki67 as decribed above.

\section{Blood glucose tolerance test}

Wild-type and FRK k/o mice of 3-5 months of age were given a single dose of $250 \mu 1$ $30 \% \mathrm{w} / \mathrm{v}$ glucose intrav enously. Blood was withdrawn from the tail, prior to injection and then at 10, 30, 60 and $120 \mathrm{~min}$ after injection. Blood glucose was measured with Freestyle mini system (Abbot, TheraSense Inc, Alameda, CA, USA). Number of animals: wild-type $\mathrm{n}=5, \mathrm{FRK}-\mathrm{-}-\mathrm{n}=9$.

\section{Histological evaluation}

Alpha and beta cell area determination: Slides were blinded and the percentage of insulin or glucagon positive area relative to total pancreas area was determined on photos of stained sections using Photoshop 6.0 with Image Process ing Toolk it v3.0. For E15.5: Insulin: wild-type n=3, FRK-/- n=5, 3-5 sections/pancreas. Glucagon: wild-typ e n=3, FRK-/- n=4, 2-3 sections/pancreas. For day 1: Insulin: wild type $n=6$, FRK-/- $\mathrm{n}=5,2-3$ sections/pancreas. Glucagon: FRK+/- n=3, FRK-/- n=3, 3 sections per pancreas. For 2.5 months: The pancreas was rolled into a ball prior to fixation and 
sections from three different levels of the pancreas were stained with insulin: wildtype $n=6, F R K-/-n=5$.

The percentage of proliferative islet cells was ass essed by counting the number of Ki67-positive islet cells per total number of islet cells, on sections from three levels or more. Islet cells were counted until at least 20 positive cells had been counted in each pancreas. This led to a total islet cell count between 2189-8152 cells in different pancreata, (median 4708). For one pancreas only 14 positive cells was found of counted 7936 islet cells. For the proliferation study, pancreata were collected from wild-type (n=5) and FRK -/- $(n=6)$ mice of 3-5 mon ths of age.

Double staining of pancreas with Ki67 and insulin was achieved on a smaller number of sections. Insulin and Ki67 double positive cells were counted on these sections. Number of insulin positive cells counted, were 743-4708 per pancreas, (median 2189). wild-type $(n=5)$ and FRK -/- $(n=4)$ mice of 3-5 months of age.

\section{Statistics}

Means \pm SEM were calculated and comparisons were made with unpaired twosample Student's t-test using SigmaStat ${ }^{\circledR}$ (SPSS Inc., Chicago IL, USA). Before comparison of data was performed, data was tested and found to be normal distributed. P-values, less than 0.05 were considered significant.

\section{Results}

The FRK-/- mouse has previously been reported to be healthy. A complete histopathological examination of animals of different ages did not reveal any histolo gical abnormalities, nor did FRK-/- an imals develop any pathological or metabolic disorders associated with failure of epithelial organs (Chandrasekharan et al. 2002). However, any detailed investigation of the pancreatic endocrine mass and function in FRK-/- mice has not been published.

Since transgen ic mice expressing FRK under the rat insulin promoter exhibited increased beta cell area at three months of age (Anneren and Welsh 2001), the beta cell area was determined in FRK-/- mice of similar age (2.5 month old) (Fig 1A). The beta cell area in FRK-/- was equal to that of wild-type, suggesting that absence of FRK does not affect the adult beta cell mass. To address whether the absence of FRK inflicts changes in endocrine cell turnover, islet cell proliferation in FRK-/- animals was investigated using staining for the cell proliferation associated nuclear antigen 
Ki67 (Gerdes, et al. 1984). The proliferative index of islet cells and beta cells in FRK-/- animals was found to be similar to that of wild-type animals (Fig 1B). To assess adult beta cell/pancreatic endocrine function, 3-5 month old FRK-/- and wildtype animals were subjected to an intravenous blood glucose tolerance test (Fig 1C). The FRK-/- mice responded normally to the glucose challenge and did not show any deficiency in blood glucose con trol when compared to wild-type mice. In addition, there were no differences in absolu te pancreas weight, pancreas weight/body weight or in body weight between 3-5 month old FRK-/- $(n=9)$ and wild-type $(n=5)$ mice (data not shown).

Little is known about the function of FRK during embryogenesis and foetal development. One study reported that FRK is highly expressed at E18, in rat foetal gut epithelium during the transition from undifferentiated stratified epithelium to the formation of primordial villi covered by a polarized epithelial monolayer (Sunitha and Avigan 1996). We have previously reported expression of FRK in foetal rat islets (Oberg-Welsh and Welsh 1995). However, no study so far has investigated the role of FRK in embryonal pancreatic endocrine cell differentiation and foetal development. To address this, pancreata from embryonal day E15.5 and neonatal day 1 were collected and prepared for histological analysis. Sections were made and stained for insulin or glucagon, followed by determination of insulin and glucagon positive areas. At embryonal day 15.5, the relative insulin positive area in FRK-/- mice was found to be reduced, while the relative glucagon positive area appeared to be increased, although not significantly (Fig 2A, 2B). The combined area of insulin and glucagon stained cells was almost identical in wild-type and FRK-/- mice (Fig 2C).

On day 1 neonatally, the relative insulin area in FRK-/- mice was also reduced, although to a lesser degree than at E15.5 (Fig 3A). Due to a lack of a sufficient number of wild-type neonatal mice, further comparison of neonatal mice was performed using FRK+/- as control. There was no difference in glucagon positive area between FRK+/- and FRK-/- mice (Fig 3B). FRK-/- mice on day 1 after birth were indistinguishable from FRK +/- littermates, with regards to body weight, pancreatic weight or pancreatic/body weight (Fig 3C, data not shown), indicating that absence of FRK does not affect body weight or overall growth of the pancreas. 


\section{Discussion}

The results in this study point to a role of FRK in regulating the beta cell number during development, assuming that no change in cell volume takes place. The effect of FRK absence was most marked during embryogenes is and becoming less apparent with age. These findings suggest that FRK plays a non-redundant role for beta cell number during embryogenesis and early postnatal life, while being redundant for the beta cell number during adult life. These findings may appear contradictory to the RIP-FRK mice, which display almost a two-fold increase in the relative beta cell area and slightly enlarged pancreas at 3-5 months of age (Anneren and Welsh 2001). FRK expression in the RIP-FRK transgenic mouse does not, however, reflect the normal physiological levels of FRK, nor does it exhibit normal timing of FRK levels at different stages of development since FRK-expression follows the activation of the rat insulin promoter. In addition, a constitutively active FRK-mutant was used for these experiments.

A possible problem with determining the endocrine area in relation to total pancreas area is that an increase in the exocrine proportion of the pancreas would theoretically give the same results as a decrease in the endocrine proportion. However, such an increase or decrease in exocrine tissue would show off as an easily detectable alteration of pancreas size, due to the fact, that the exocrine part of the pancreas is so much larger than the endocrine. Pancreas size of FRK-/- mice at neonatal day 1 did not differ from that of FRK+/-, arguing that the changes in beta cell mass observed in this study are due to alterations of the endocrine cell mass and that the exocrine part of the pancreas is not affected.

At E15.5 the FRK-/- pancreas displayed a reduced insulin positive area while the glucagon positive area appeared to be increased, thus the total area of glucagon and insulin positive cells in the FRK-/- was very similar to the corresponding total area in the wild type. It is thus tempting to speculate that FRK may influence endocrine cell fate specification, with its absence increasing the number of alpha cells and reducing beta cell specification at this stage of development. In adult life, regulation of beta cell mass is positively affected by signalling through insulin receptor substrate (IRS) 2protein. IRS2 mediates signals from the insulin and IGF1 receptors, activating the downstream pathways PI3K-Akt and Grb2-Ras-Erk 1/2 promoting beta cell survival and replication (White 2006). Islets from the RIP-FRK transgenic mouse show a trend 
to increased basal IRS2 phosphorylation (Anneren and Welsh 2002). Insulin stimulation does not lead to further activation of IRS2, indicating perturbed IRS2 signaling. FRK-transfected RINm5F-cells display increased basal IRS2 phosphorylation and reduced relative phosphorylation upon insulin stimulation. In addition, there is increased basal activity of PI3-kinase and of ERK1/2, whereas insulin induced activation of PI3Kinase, ERK1/2 and AKT are reduced. Thus has FRK been suggested to affect beta cell number through activation of IRS2-signaling. However, the lack of a clear phenotype in adult FRK-/- mice indicates that FRK probably is redundant under normal conditions for IRS2-mediated regulation of the beta cell mass.

During the embryonal development of the pancreas, the expansion of the beta cell mass is predominantly driven by neogenesis from endocrine precursors situated in the pancreatic epithelium. After birth neogenesis diminishes and beta cell replication becomes the main mechanism for increasing the beta cell mass. The role of IRSmediated signaling for beta cell differentiation and expansion during the embryonal and perinatal stages has not been extensiv ely studied. It has been reported that IRS1+/-, IRS2 -/- mice and IGF 1R -/- mice exhibit a reduced number of beta cells at E18.5, however these mice also display a general growth retardation (Liu, et al. 1993; Withers, et al. 1998). In mice with selective IRS2 deletion by RIP-driven Creexpression, the beta cell area and proliferation is unaffected on day 10 after birth. Later on, these mice display a reduced beta cell area and proliferation at 8 and 12 weeks of age (Kubota, et al. 2004). A recent study described that fetal rat islets isolated from litters of undernourished mothers differed from islets from litters of control mothers, in regard to increased islet replication. This was coupled to an increased IRS2 protein content and an enhanced glucose/IGF-1 stimulation of the IRS2/PI3K/PKB pathway (Fernandez, et al. 2007). From these reports, it is not possible to deduce if IRS2-signaling is stric tly necessary for beta cell mass expansion during the embryonal development of the endocrine pancreas although signalling through IRS2 positively affects the beta cell mass.

Another system operating during late embryonal development in endocrine differentiation is signalling through the ErbB-1 receptor (Huotari, et al. 2002; Miettinen, et al. 2000). However, the main changes observed as a consequence of perturbing this system were observed on day E18.5 rather than day E15.5, making it unlikely that the FRK effects presently observed involve ErbB-1 signalling. 
Taken together this study shows that FRK is involved in regulating the beta cell number during embryonal and early postnatal life. More knowledge of the precise action of FRK may give valuable clues for the understanding of pancreatic beta cell number regulation.

\section{Acknowledgements}

We are grateful to Subhashini Chandrasekharan and Edison T Liu for providing the FRK-/- mouse. We are also grateful to Ing-Britt Hallgren for excellent assistance with FRK -/- mice and pancreas preparation, to Astrid Nordin for kindly performing i.v. glucose injections and to Eva Törnelius for excellent assistance with histological preparation and staining. The study was supported by the Swedish Research Council (31X-10822), the Juvenile Diabetes Research Foundation International, the Swedish Diabetes Association, the Swedish Cancer Foundation, the Family Ernfors Fund and Innoventus Project AB.

\section{List of Abbreviations}

ERK extracellular-signal regulated kinase; FRK Fyn-Related Kinase; IGF1R insulinlike growth factor 1 receptor; IRS insulin receptor substrate; PAP Peroxidase AntiPeroxidase; PBS phosphate buffered saline; PI3K phosphatidyl ino sitol 3 kinase; PKB protein kinase B; RIN rat insulinoma; RIP Rat Insulin Promotor; TBS tris buffered saline. 


\section{References}

Anneren C 2002 Dual role of the tyrosine kinase GTK and the adaptor protein SHB in beta-cell growth: enhanced beta-cell replication after $60 \%$ pancreatectomy and increased sensitivity to strep to zotocin. J Endocrinol 172 145-153.

Anneren C \& Welsh M 2001 Increased cytokine-induced cytotoxicity of pancreatic islet cells from transgenic mice expressing the Src-like tyrosine kinase GTK. Mol Med 7 301-310.

Anneren C \& Welsh M 2002 GTK tyrosine kinase-induced alteration of IRS-protein signalling in insulin producing cells. Mol Med 8 705-713.

Chandrasekharan S, Qiu TH, Alkharouf N, Brantley K, Mitchell JB \& Liu ET 2002 Characterization of mice deficient in the Src family nonreceptor tyrosine kinase Frk/rak. Mol Cell Biol 22 5235-5247.

Fernandez E, Martin MA, Fajardo S, Escriva F \& Alvarez C 2007 Increased IRS-2 content and activation of IGF-I pathway contribute to enhance beta-cell mass in fetuses from und ernourished pregnant rats. Am J Physiol Endocrinol Metab 292 E187-195.

Gerdes J, Lemke H, Baisch H, Wacker HH, Schwab U \& Stein H 1984 Cell cycle analysis of a cell proliferation-associated human nuclear antigen defined by the monoclonal antibody Ki-67. J Immunol 133 1710-1715.

Huotari MA, Miettinen PJ, Palgi J, Koivisto T, Ustinov J, Harari D, Yarden Y \& Otonkoski T 2002 ErbB signaling regulates lineage determination of developing pancreatic islet cells in embryonic organ culture. Endocrinology 143 4437-4446. Kubota N, Terauchi Y, Tobe K, Yano W, Suzuki R, Ueki K, Takamoto I, Satoh H, Maki T, Kubota T, et al. 2004 Insulin receptor substrate 2 plays a crucial role in beta cells and the hypothalamus. J Clin Invest 114 917-927.

Liu JP, Baker J, Perkins AS, Robertson EJ \& Efstratiadis A 1993 Mice carrying null mutations of the genes encoding insulin-like growth factor I (Igf-1) and type 1 IGF receptor (Igflr). Cell 75 59-72.

Miettinen PJ, Huotari M, Koivisto T, Ustinov J, Palgi J, Rasilainen S, Lehtonen E, Keski-Oja J \& Otonkoski T 2000 Impaired migration and delayed differentiation of pancreatic islet cells in mice lacking EGF-receptors. Development 127 2617-2627.

Oberg-Welsh C \& Welsh M 1995 Cloning of BSK, a murine FRK homologue with a specific pattern of tissue distribution. Gene 152 239-242.

Sunitha I \& Avigan MI 1996 The apical membranes of maturing gut columnar epithelial cells contain the enzymatically active form of a newly identified fyn-related tyrosine kinase. Oncogene 13 547-559.

Welsh M, Welsh C, Ekman M, Dixelius J, Hagerkvist R, Anneren C, Akerblom B, Mahboobi S, Chandrasekharan S \& Liu ET 2004 The tyrosine kinase FRK/RAK participates in cytok ine-induced islet cell cytotoxicity. Biochem J 382 261-268. White MF 2006 Regulating insulin signaling and beta-cell function through IRS proteins. Can J Physiol Pharmacol 84 725-737.

Withers DJ, Gutierrez JS, Towery H, Burks DJ, Ren JM, Previs S, Zhang Y, Bernal D, Pons S, Shulman GI, et al. 1998 Disruption of IRS-2 causes type 2 diabetes in mice. Nature 391 900-904. 


\section{Figure legends}

\section{Figure 1}

A. Pancreata from 2.5 month old wild-type and FRK -/- were stained for insulin and the percent in sulin positive area was determined. Insulin wild-type $n=6, F R K-/-n=5$, B. Proliferation of islet cells in 3-5 months old FRK-/- and wild-type mice, based on (1) number of Ki67-positive islet cells per total number of islet cells or (2) number of Ki67 and insulin double positive cells per total number of insulin positive cells. Number of animals (1): wild-type ( $\mathrm{n}=5)$ and FRK $-/-(\mathrm{n}=6)$. Number of animals (2): wild-type $(n=5)$ and FRK -/- $(n=4)$. For number of levels examined and number of cells counted please see the section Histological Evaluation in Material and Methods. C. Intravenous glucose tolerance test: Wild-type and FRK -/- mice of 3-5 months of age were given a single dose of $250 \mu 130 \% \mathrm{w} / \mathrm{v}$ glucose i.v. Blood glucose was measured, prior to injection and subsequently at 10,30,60 and $120 \mathrm{~min}$. Number of animals included were wild-type $=5$, FRK $-/-=9$. Error bars show SEM. No error bars are shown for the $10 \mathrm{~min}$ value, due to certain values out of range of blood glucose measuring equipment, $\max 27.8 \mathrm{mM}$.

\section{Figure 2}

A. Representative pictures of same magnification, of E15.5 wild-type or FRK-/pancreata, immunohistochemically stained for insulin or glucagon.

B. The relative insulin cell area in FRK-/- mice was decreased at embryonal day 15.5 ( $31 \%$ of wild type, $p<0,05$ ). Insulin wild-type $n=3, F R K-/-n=5,3-5$ sections/pancreas. Glucagon wild-type $n=3$, FRK-/- $n=4,2-3$ sections/pancreas. * Denotes a $p$-value $<0.05$ by Student's unpaired t-test.

C. Combined relative insulin and glucagon positive area at E15.5. The total area of insulin and glucagon positive cells, taken together appears to be identical.

\section{Figure 3}

A. Pancreata of day 1 wild-type or FRK -/- neonatal mice were stained for insulin. The relative insulin cell area in FRK-/- mice was moderately reduced at day 1 (70\% of wild type, $p<0,05$ ). For insulin, the numbers of pancreata were for wild-type 6 and 
for FRK-/- 5, respectively. 2-3 sections/pancreas were analysed. * Denotes a p-value $<0.05$ by Student's unpaired t-test.

B. Pancreata of FRK +/- or FRK -/- neonatal mice were stained for glucagon.

The number of pancreata analysed were 3 for FRK+/- and 3 for FRK-/-, 3 sections per pancreas were analysed.

C. The mean pancreas weight of newborn FRK+/- and FRK-/- mice. FRK+/- $n=6$, FRK-/- $n=6$. 
Figure 1A.

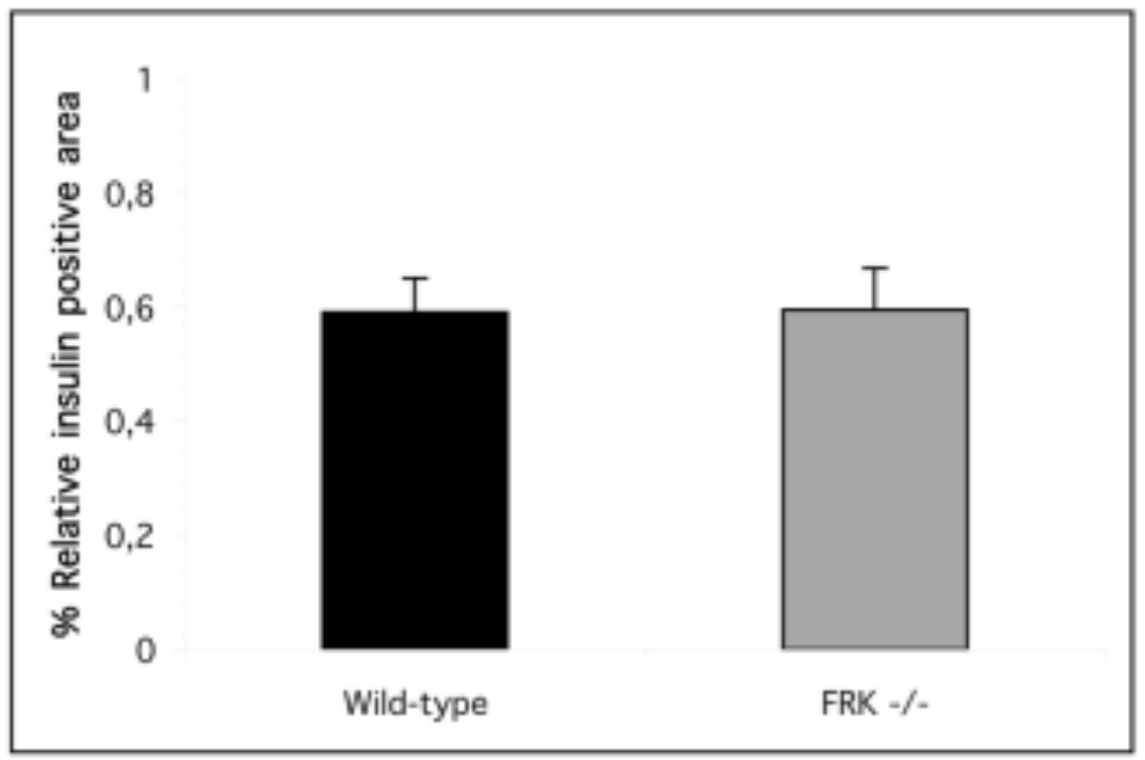

Figure 1B.

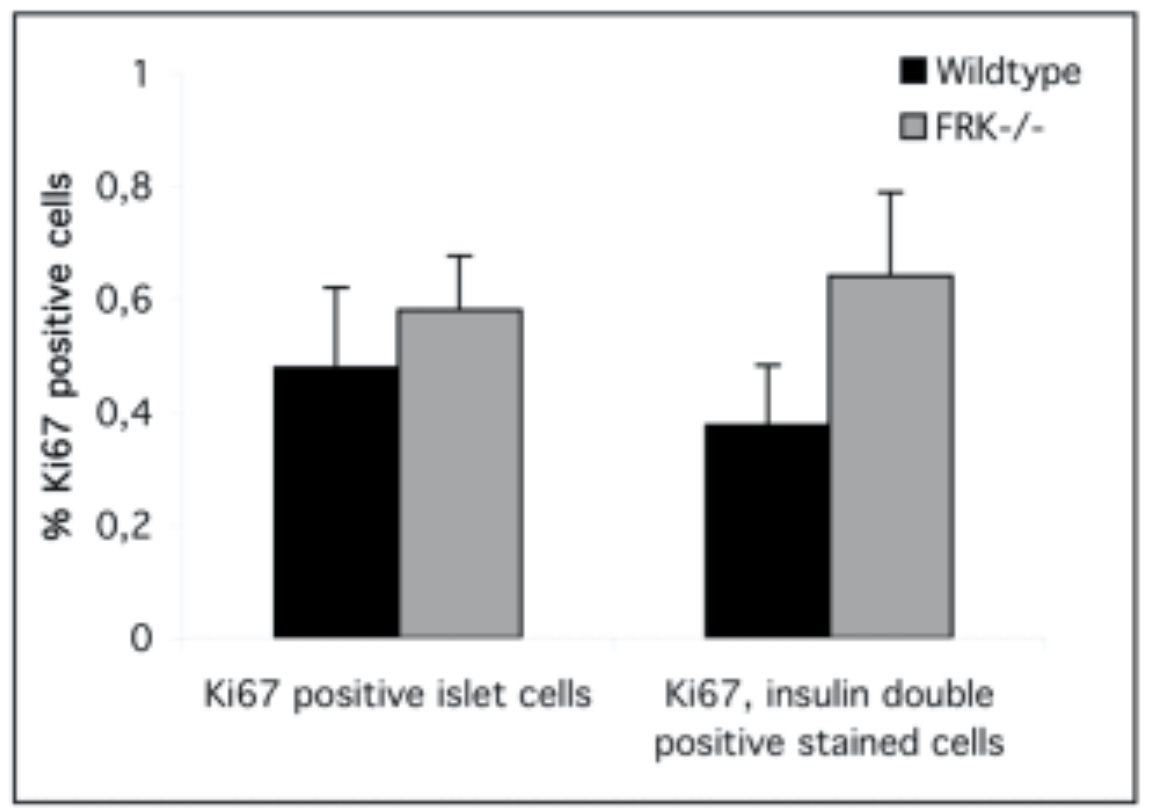


Figure 1C.

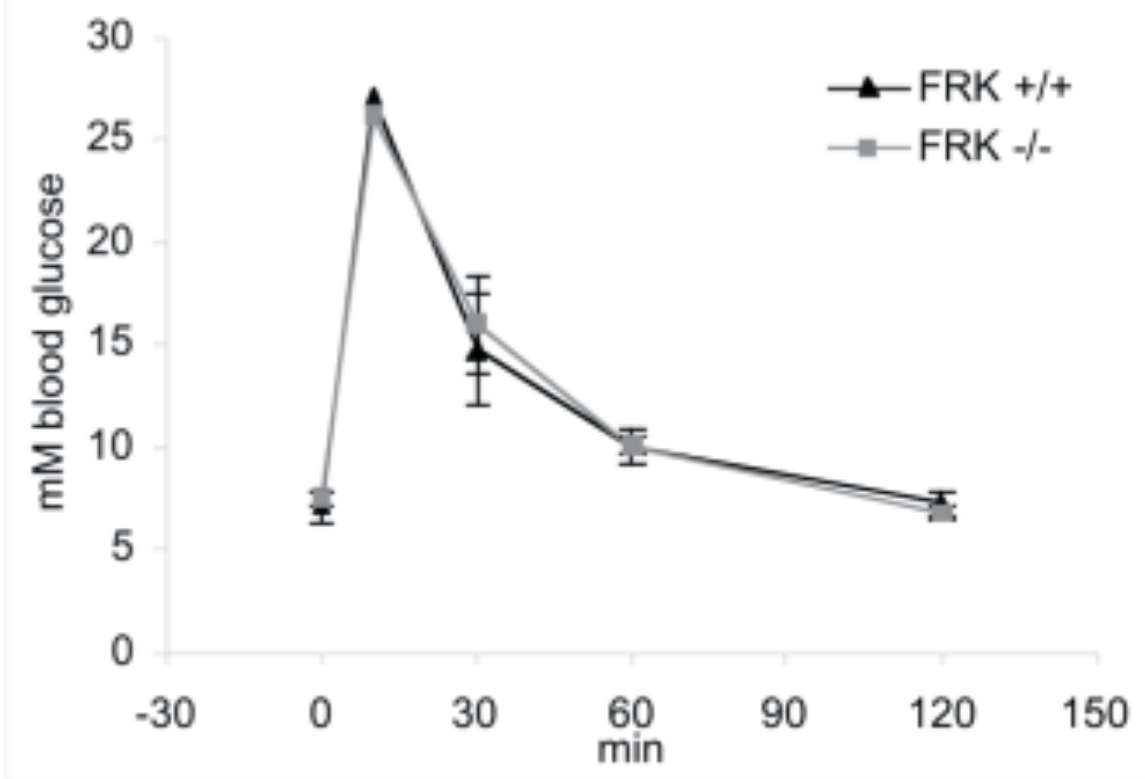


Figure 2A.
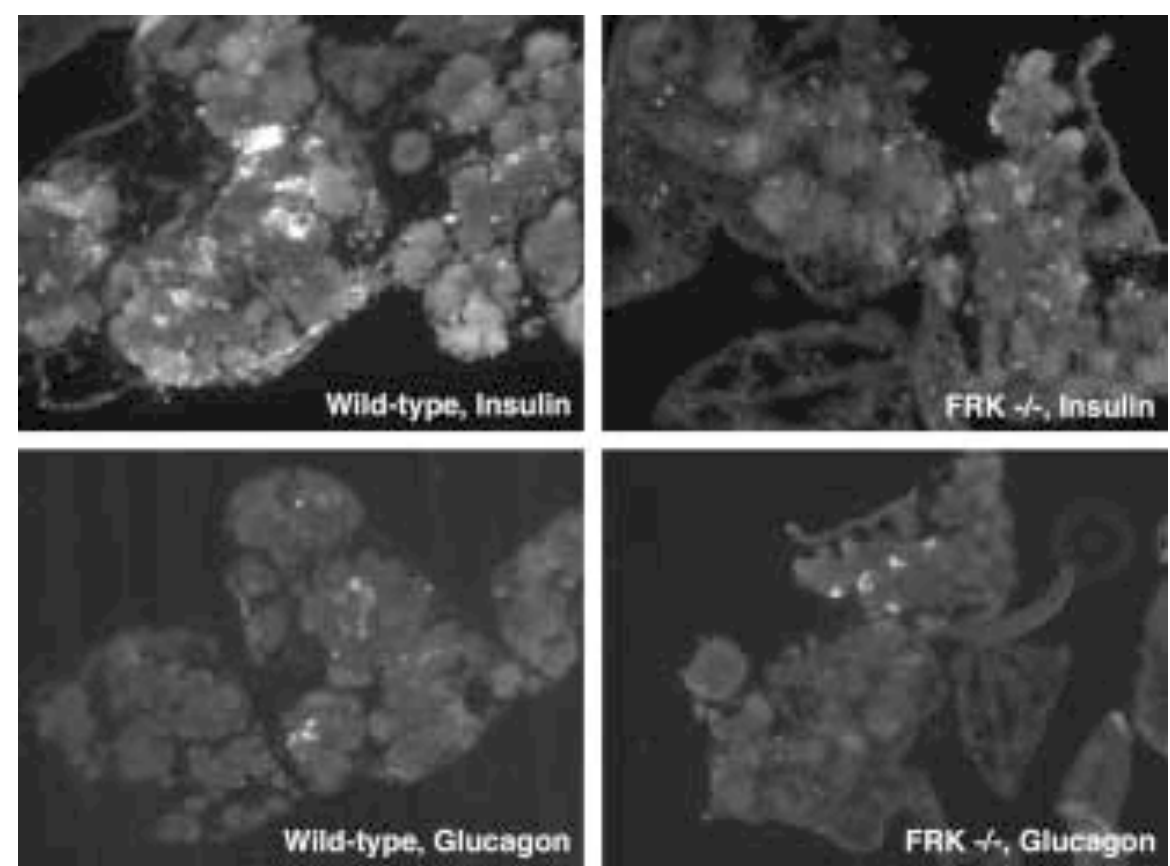

Figure 2B.
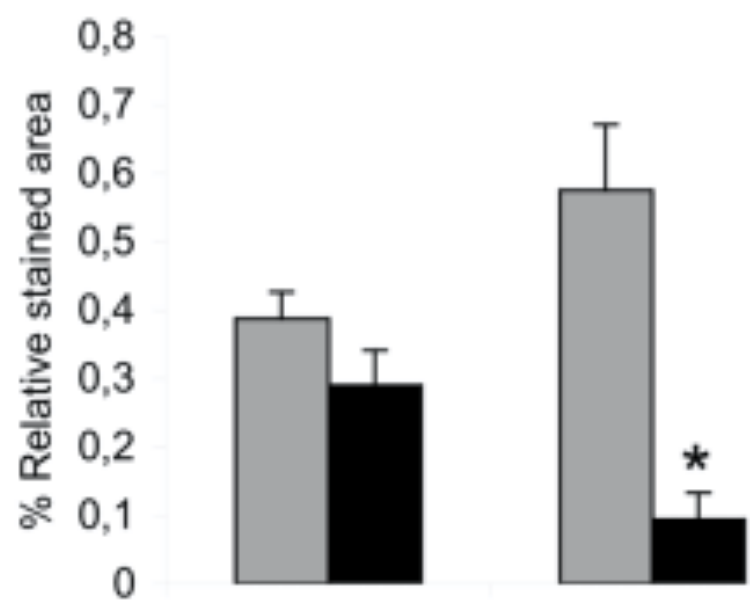

$\square$ Glucagon

- Insulin

FRK +/+

FRK -1- 
Figure 2C.

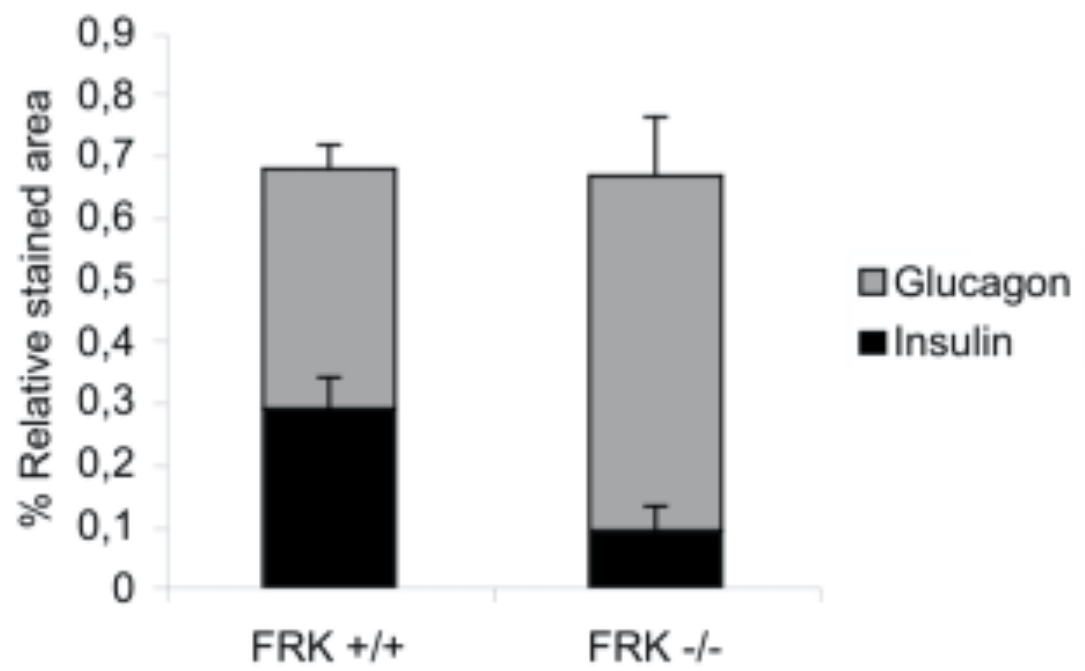


Figure 3A.

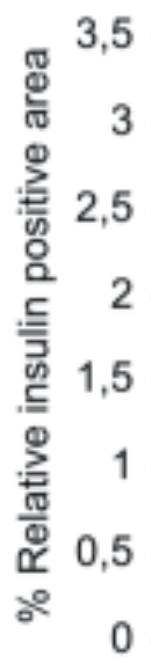

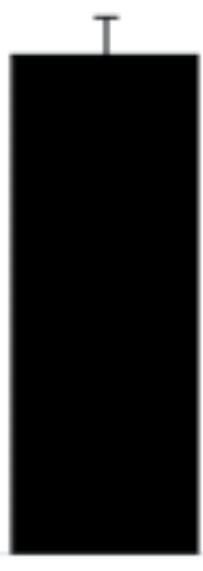

FRK +/+

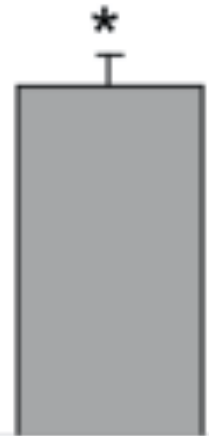

FRK -/-

Figure 3B.
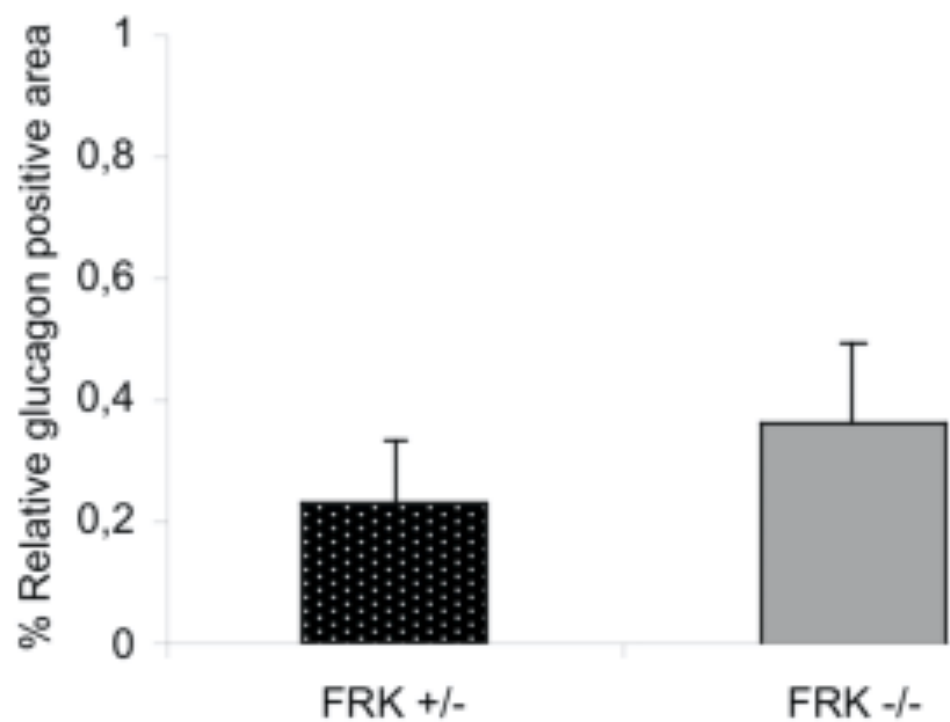
Figure 3C.

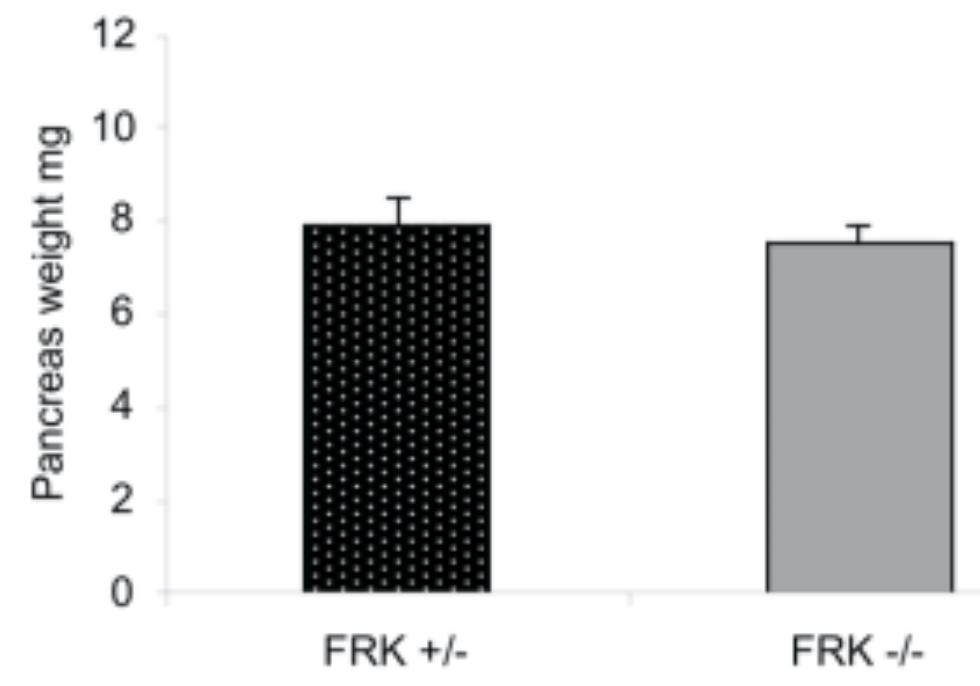

